\title{
Mast cells in the kidney biopsies of pediatric patients with lupus nephritis
}

\author{
Mastócitos em biópsias renais de pacientes pediátricos com nefrite
} lúpica

\section{Authors}

Stéfany Silva Santos ${ }^{1}$ iD

Carolina Marques Ramos ${ }^{1}$ iD

Maria Luiza Gonçalves dos Reis Monteiro ${ }^{1}$

Juliana Reis Machado' ${ }^{1}$ iD Marlene Antônia dos Reis ${ }^{1}$ iD Rosana Rosa Miranda Corrêa ${ }^{1}$ Laura Penna Rocha ${ }^{1}$ iD

1 Universidade Federal do Triângulo Mineiro, Instituto de Ciências Biológicas e Naturais, Departamento de Patologia Genética e Evolução, Setor de Patologia Geral, Uberaba, MG, Brasil.

Submitted on: 11/06/2018. Approved on: 10/15/2019.

\section{Correspondence to:}

Laura Penna Rocha.

E-mail: laura.rocha@uftm.edu.br

DOI: 10.1590/2175-8239-JBN-2018-0222

\section{Abstract}

Introduction: Mast cells may be involved in inflammation and contribute to the onset of fibrosis in lupus nephritis (LN). Objective: This study aimed to correlate the presence of mast cells in kidney biopsy specimens of pediatric patients with LN with activity (AI) and chronicity (CI) indices and assess how effectively mast cells may be used as a prognostic factor. Method: The study included 40 patients aged 6-18 years diagnosed with $\mathrm{LN}$ at the Renal Disease Service of the Federal University of Triângulo Mineiro between 1996 and 2015. Workup and epidemiological data were evaluated vis-à-vis AI, CI, and mast cell counts (MCC). Results: Significant positive correlations were found between mast cell counts (MCC) and $\mathrm{AI}(p=0.003 ; \mathrm{r}: 0.66)$ and MCC and CI $(p=0.048 ; \mathrm{r}: 0.48)$. The ROC curve showed that mast cells were highly sensitive and specific in the differentiation of patients with an $\mathrm{AI}>12$ from individuals with an $\mathrm{AI} \leq 12$. Serum creatinine levels were higher in individuals with class IV $\mathrm{LN}$ than in patients with class $\mathrm{V}$ disease [1.50 (0.40-20.90) vs. $0.70(0.62-0.90), p$ $=0.04]$. Blood urea nitrogen had a positive significant correlation with MCC $(p=$ 0.002; r: 0.75). A trend toward a negative correlation was observed between MCC and serum albumin ( $p=0.06$; $\mathrm{r}:-0.5459)$. Kidney biopsies of patients with nephrotic syndrome had higher MCC [2.12 (0.41$5.140)$ vs. $0.53(0.0-3.94), p=0.07]$. Conclusion: Inflammatory cell infiltration and morphological differences between cell types in the inflammatory infiltrate are relevant factors in the assessment of the LN. Mast cell analysis and AI/CI assessment may be relevant prognostic indicators for pediatric patients with LN.

Keywords: Lupus Nephritis; Mast Cells; Pediatrics.

\section{Resumo}

Introdução: Mastócitos podem participar da inflamação e contribuir para fibrose na nefrite lúpica (NL). Objetivo: Correlacionar mastócitos em biópsias renais (BR) de pacientes pediátricos com NL com índices de atividade (IA) e cronicidade (IC), avaliando sua efetividade como fator prognóstico. Metodologia: Foram estudados 40 pacientes, entre 6 e 18 anos, diagnosticados com NL pelo Serviço de Nefropatologia da UFTM entre 1996 e 2015. Dados laboratoriais e epidemiológicos foram correlacionados com IA, IC e contagem de mastócitos (CM). Resultados: Encontramos correlação positiva e significativa entre contagem de mastócitos (CM) e IA ( $p$ $=0,003 ; \mathrm{r}: 0,66)$ e entre $\mathrm{CM}$ e IC $(p=$ 0,$048 ;$ r: 0,48). Conforme a curva Roc, os mastócitos têm alta sensibilidade e especificidade na diferenciação de pacientes com IA menor ou maior do que 12. A creatinina sérica foi mais elevada na classe IV em relação à classe $\mathrm{V}[1,50$ $(0,40-20,90)$ versus $0,70(0,62-0,90)$, $p=0,04]$. Ureia sérica apresentou correlação positiva e significativa com $\mathrm{CM}$ $(p=0,002 ; \mathrm{r}: 0,75)$. Observou-se tendência à correlação negativa entre $C M$ e albumina sérica ( $p=0,06$; r: -0,5459). BR de pacientes com síndrome nefrótica apresentaram maior CM $[2,12(0,41$ $5,140)$ versus $0,53(0,0-3,94), p=$ 0,07]. Conclusão: Não apenas o infiltrado inflamatório como também a diferenciação morfológica dos tipos celulares que o constituem são importantes para a avaliação da NL. Isso indica que a análise dos mastócitos, juntamente com a dos IA e IC, pode ajudar os nefrologistas a definirem o prognóstico de pacientes pediátricos.

Palavras-chave: Nefrite Lúpica; Mastócitos; Pediatria. 


\section{INTRODUCTION}

Systemic lupus erythematosus (SLE) is an autoimmune condition triggered by lymphocyte self-tolerance loss, an event that makes them autoreactive and leads to the formation of multiple autoantibodies and potential end-organ damage. ${ }^{1,2}$ Renal involvement by SLE is called lupus nephritis (LN), a condition known for myriad histopathology variations that may affect all compartments of the kidneys, and a consequently wide array of clinical and morphological manifestations.

The identification of the factors preceding the onset of renal failure and fibrosis is a relevant effort and possibly an important element in defining patient prognosis. Fibrosis develops via pathophysiological mechanisms that act independently from the primary cause of injury, and consists of the excessive accumulation of extracellular matrix replacing normal renal parenchyma. ${ }^{3,4,5}$ Mast cells contribute to renal fibrosis and mast cell counts have been correlated with the severity of tubulointerstitial injury. ${ }^{6}$

Mast cells are traditionally subdivided into two phenotypes: mast cells secreting tryptase and chymase and mast cells secreting only tryptase. Tryptases are known for their involvement in increased fibroblast (FB) proliferation; increased FB collagen synthesis and IL6 production; increased FB chemotaxis; increased differentiation of FB into myofibroblasts; increased FB contractility; decreased FB apoptosis; activation of epithelial cells and TGFB1; and increased angiogenesis and neutrophil recruitment. The primary functions of chymase granules include conversion of procollagen type 1 into collagen; conversion of angiotensin I into angiotensin II; and protection against fibrosis in ureteral obstruction models. In sum, mast cells secreting tryptase might be involved in immune response, while mast cells secreting chymase might have an additional role in angiogenesis and tissue remodeling. ${ }^{7,8}$ In the kidneys, mast cells are rarely seen in the glomerular compartment. Mast cells in the renal interstitium are predominantly of the tryptase-secreting type, although the tryptase and chymase-secreting type is found in the tubulointerstitial compartment in some renal conditions, albeit to a lesser degree. ${ }^{8}$

Some of the morphological signs observed in the kidney biopsies of patients with lupus nephritis may be used to predict disease progression and help nephrologists to define the type and intensity of immunosuppressant therapy required. For this reason, authors proposed the segregation of active and chronic disease based on activity (AI) and chronicity (CI) indices. ${ }^{9}, 10,11$

Despite the significant risk of tissue damage, active disease can be reversed and has been associated with better response to immunosuppressant therapy. However, patients with a higher CI are at greater risk of developing chronic kidney disease. Aggressive therapy is thus recommended to individuals with low-tomedium CI so as to maximize the recovery of renal function. ${ }^{12}$

Based on these findings, this study looked into mast cells and interstitial fibrosis in kidney biopsy specimens of pediatric patients with $\mathrm{LN}$ and analyzed them for possible correlations with AI and CI. The study also reviewed possible correlations between histopathology, clinical, and workup findings considering patient LN classes assigned based on the examination of kidney biopsy specimens, since few studies have looked at pediatric LN.

\section{Objectives}

The primary purpose of this study was to assess the role of mast cells in pediatric patients with $\mathrm{LN}$, the associations between mast cells and activity and chronicity indices, and whether mast cells may be seen as a prognostic factor.

\section{Materials ANd methods}

The Ethics Committee of the Federal University of Triângulo Mineiro approved this study and assigned it certificate no. 1740. The authors collected workup (urine protein, blood urea nitrogen, and creatinine levels) and epidemiological data (age, sex, and skin color). Forty children and adolescents aged 6-18 years submitted to kidney biopsies and diagnosed with lupus nephritis between 1996 and 2015 at the Renal Pathology Service of the Federal University of Triângulo Mineiro, in Uberaba.

Lupus nephritis classification was performed in accordance with the criteria established by the International Society of Nephrology (ISN) and the Renal Pathology Society (RPS) in 2004.

AI and CI were calculated only for individuals with class IV LN, since this was the most prevalent condition on our group. AI is determined based on analysis for endocapillary hypercellularity, glomerular leukocyte infiltration, subendothelial hyaline deposits, and interstitial inflammation. Each finding is 
graded on a scale of 0 to 3. Fibrinoid necrosis, karyorrhexis, and cellular crescents are also individually analyzed and graded on a scale of 0 to 3 . However, since they are more severe, the outcome is multiplied by two. Therefore, AI may range from 0 to 24 . CI is based on findings such as glomerulosclerosis, fibrous crescents, interstitial fibrosis, and tubular atrophy. Each finding is graded on a scale of 0 to 3 . Therefore, CI may range from 0 to $12 .{ }^{8,9}$

A renal pathologist examined all the cases included in this study. Mast cells were counted with the aid of Giemsa staining, in which mast cells are stained magenta on account of their ability to show metachromasia.

Mast cells possess peculiar histological traits. They have secreting cytoplasmic granules equipped with the ability to show metachromasia when processed with Romanowsky stains, which include the Giemsa and toluidine blue stains, to name a few. Metachromasia allows the studied histological structure to stain in a different color than the dye. Studies have shown that the Giemsa and toluidine blue stains are equally effective at identifying mast cells in the kidneys. However, the two stains cannot differentiate mast cells secreting tryptase and chymase from mast cells secreting tryptase only. ${ }^{13,14}$

Mast cells were counted throughout the entire extent of the biopsy specimens and counts were expressed in cells $/ \mathrm{mm}^{2}$ under $40 \mathrm{x}$ magnification (final magnification 1600x). Area calculations were performed with the aid of a stage micrometer measuring $1000 \mu \mathrm{m}$, from which the diameter of the field of view of a light microscope was measured. The area of the field was then calculated $\left(\mathrm{A}=\varpi \times \mathrm{r}^{2}\right)$ and converted to $\mathrm{mm}^{2}$.

Picro-sirius red staining was used to characterize interstitial fibrosis. The natural birefringence of collagen-rich areas highlighted under polarized light shows as a reddish color. These areas are marked by an observer with image analysis tool Leica Qwin ${ }^{\circledR}$ on 40x magnification (final magnification $1250 x$ ) only in the tubules and interstitium. The entire extent of the biopsy specimens was analyzed. After the area of interest has been defined, the analysis software expresses the outcome as a proportion of the delimited area.

Microsoft Excel was used in statistical analysis. Data analysis was performed on software package GraphPad Prism version 5.00. Quantitative variables were tested for normality with the KolmogorovSmirnov test. Variables from the two groups following a normal distribution and with similar variance were compared with Student's t-test. The results were expressed as mean value \pm standard error $(\mathrm{X} \pm \mathrm{SE}$ ). Variables from the two groups not following a normal distribution or following a normal distribution with non-similar variances were compared with the Mann-Whitney U test. The results were expressed in terms of median values and minimum-maximum values [Med (Min-Max)]. The correlations between two variables following a non-normal distribution were analyzed via Spearman's rank correlation coefficient; correlations between two variables following a normal distribution were analyzed via Pearson's correlation coefficient. The sensitivity and specificity of mast cell counts as a factor in the determination of activity and chronicity indices were verified based on the Receiver Operating Characteristic (ROC) curve. Differences with a calculated probability $(\mathrm{p})$ of less than $5 \%$ were deemed statistically significant $(p<$ $0.05)$.

\section{Results}

Forty pediatric patients with a mean age of $14.37 \pm$ 3.30 years $(6-18$ years) were included in the study. Most $(84.61 \%)$ were females. In terms of skin color, $71.5 \%$ were categorized as whites and $28.5 \%$ as nonwhites. A significant positive correlation was seen between age and the LN chronicity index ( $p=0.04$; Spearman's r: 0.3948) (Figure 1C). Table 1 shows clinical and histology data.

One patient $(2.5 \%)$ had class I LN; one $(2,5 \%)$ and class II LN; four (10\%) had class III LN; 24 $(60 \%)$ had class IV LN; two $(5 \%)$ had isolated class V LN; and six (15\%), had class V LN mixed with class III $(7.5 \%)$ or class IV $(7.5 \%)$ LN. Therefore, $70 \%$ of the biopsies came back with a diagnosis of proliferative (class III or IV) LN, with class IV LN being the most prevalent condition in the study. Biopsies assigned a diagnosis of class IV LN had their activity (AI) and chronicity (CI) indices calculated. The mean AI was $10.58 \pm 4.49$. The mean CI was $3.26 \pm 2.17$. Serum creatinine levels were significantly higher in the individuals diagnosed with class IV LN than in the patients with isolated class $\mathrm{V}$ LN or mixed class $\mathrm{V}$ disease $[1.50(0.40-20.90)$ vs. 0.70 (0.62-0.90), $p$ $=0.04]$. 
Figure 1. Correlations between morphological and clinical-epidemiological data of pediatric patients with Lupus Nephritis A: Correlation between number of mast cells $/ \mathrm{mm}^{2}$ and Activity Index B: Correlation between number of mast cells/mm² and Chronicity Index C: Correlation between Chronicity Index and Age D: Correlation between serum albumin and number of mast cells $/ \mathrm{mm}^{2}$

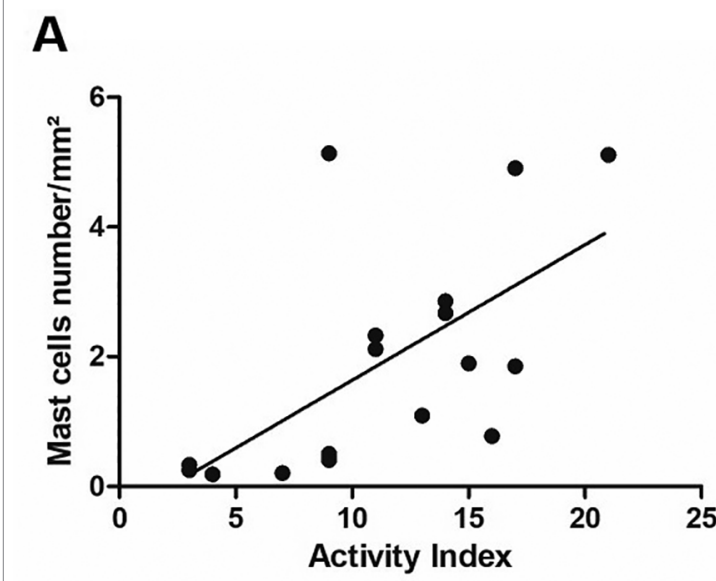

Spearman r: 0,6663; $p=0,003$

C

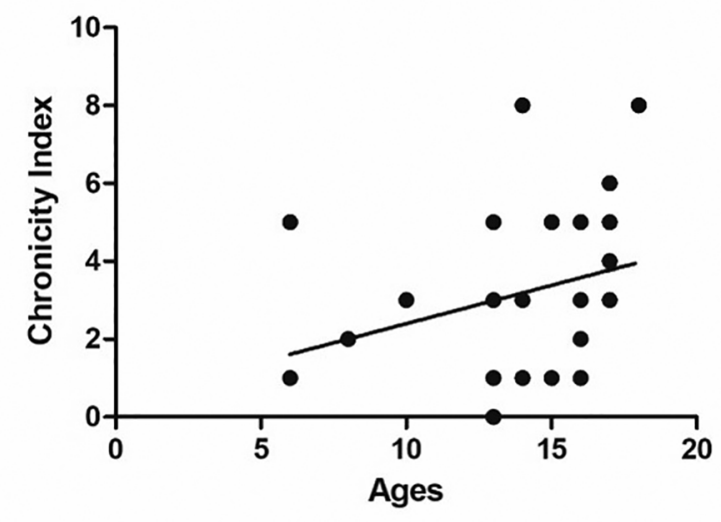

Spearman r: 0,3948; p: 0,04
B

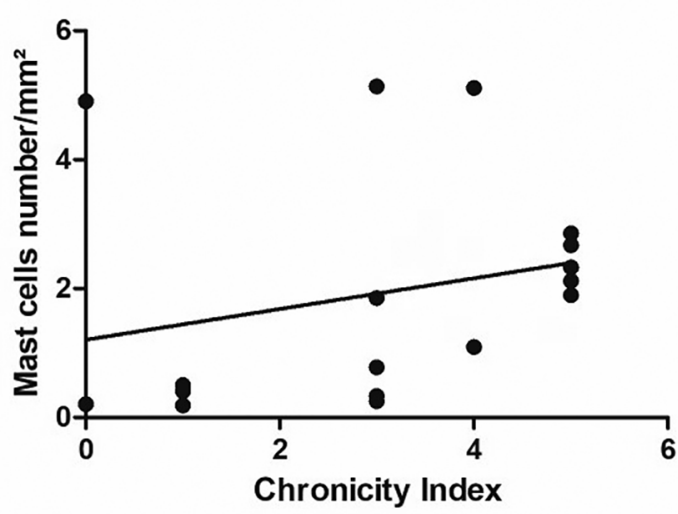

Spearman $r: 0,4857 ; p=0,048$

D

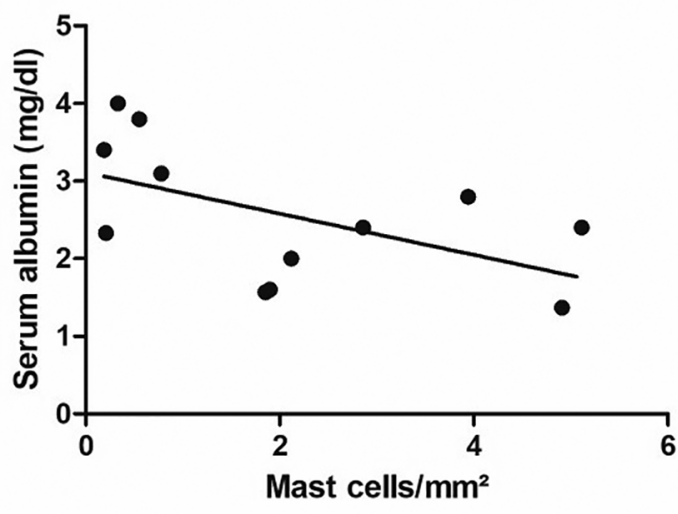

Pearson $r:-0,5459 ; p=0,06$

TABLE 1 CLINICAL AND HISTOLOgY PARAMETERS OF PEDIATRIC PATIENTS WITH LUPUS NEPHRITIS

\begin{tabular}{|c|c|}
\hline & Median (minimum-maximum) \\
\hline 24-hour urinary protein, $\mathrm{mg} / 24 \mathrm{~h}$ & $2000.00(66.00-10000.00)$ \\
\hline Creatinine, $\mathrm{mg} / \mathrm{dL}$ & $1.41(0.40-8.700)$ \\
\hline Blood urea nitrogen, mg/dL & $62.00(16.00-262.00)$ \\
\hline Albumin mg/dl & $2.40(1.37-4.00)$ \\
\hline CKD-EPI glomerular filtration rate $\left(\mathrm{mL} / \mathrm{min} / 1.73 \mathrm{~m}^{2}\right)$ & $55.30(6.20-166.00)$ \\
\hline \multicolumn{2}{|l|}{ Mast cells $/ \mathrm{mm}^{2}$} \\
\hline Class IV LN & $0.6650(0.0-5.14)$ \\
\hline Isolated or mixed Class V LN & $0.40(0.0-3.94)$ \\
\hline
\end{tabular}

Significant positive correlations were observed between mast cell counts in the tubulointerstitial compartment and the activity index ( $p=0.003$; Spearman's r: 0.6663) and between mast cell counts in the tubulointerstitial compartment and the chronicity index $(\mathrm{p}$ = 0.048; Spearman's r: 0.4857) (Figures 1A and 1B).
We split the patients into groups featuring individuals with an $\mathrm{AI}>12$, individuals with an $\mathrm{AI} \leq 12$, individuals with a $\mathrm{CI}>4$, and individuals with a $\mathrm{CI} \leq 4$, and subsequently built an ROC curve to verify whether mast cell counts might be used as a sensitive, specific, and accurate marker to differentiate between groups. 
In the group of patients with an $\mathrm{AI}>12$, an optimal cutoff set at 0.66 mast cells $/ \mathrm{mm}^{2}$ had a sensitivity of $100 \%$ [95\% confidence interval (CI): $63.06 \%$ to $100.0 \%$ ] and a specificity of $80 \%$ (95\% CI: $51.91 \%$ to $95.67 \%$ ) with an area under the curve of 0.86 and $p=0.004$ (Figure 2). The group of patients assigned a $\mathrm{CI}>4$ did not yield statistical significance.

A significant positive correlation was seen between mast cell counts in the tubulointerstitial compartment and blood urea nitrogen levels ( $p=0.002$; Spearman's $\mathrm{r}: 0.7538)$. A trend toward a negative correlation was also observed between mast cell counts in the tubulointerstitial compartment and serum albumin levels $(p=0.06$; Pearson's r: -0.5459) (Figure 1D).

Individuals with nephrotic syndrome had higher mast cell counts in the tubulointerstitial compartment than their counterparts without nephrotic syndrome [2.12 (0.41-5.140) vs. $0.53(0.0-3.94), p=0.07]$.

Figure 2. Mast cells of pediatric patients with Lupus Nephritis A: Patient with Lupus Nephritis and activity index less than or equal to 12 B: Patient with Lupus Nephritis and activity index greater than 12

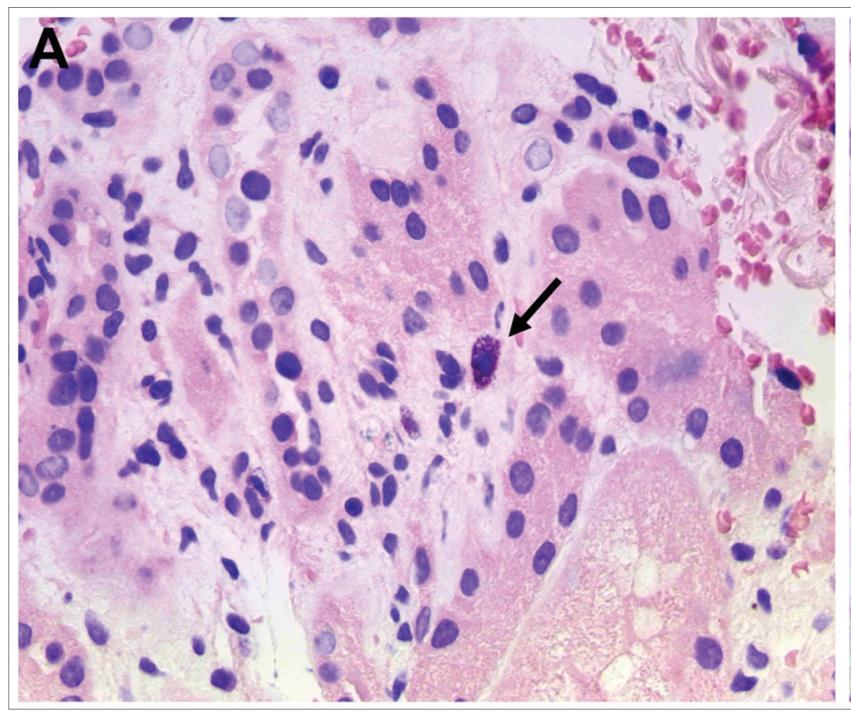

\section{Discussion}

The mean age of the patients enrolled in our study $(14.37 \pm 3.30$ years $)$ was similar to the mean age of the patients included in other studies, in which ages ranged from 9.6 to 13.6 years. ${ }^{15,16}$ The variations in mean age probably stem from geographic disparities and differences in inclusion criteria. As expected based on the natural history of the disease, a significant positive correlation was found between age and LN chronicity index, in that chronic injury develops after the disease has progressed for some time.

Most of the individuals included in our study $(84.61 \%)$ were females, as also reported in other studies enrolling pediatric populations $(80 \%$ and $81 \%$ ). ${ }^{17,18}$ In regard to skin color, $71.5 \%$ were categorized as whites. This finding disagrees with current literature, in which approximately $80 \%$ of the pediatric patients with SLE are non-whites. ${ }^{19}$ Nevertheless, some studies have also described greater proportions of white patients with LN. ${ }^{20,21}$ Our study portrayed

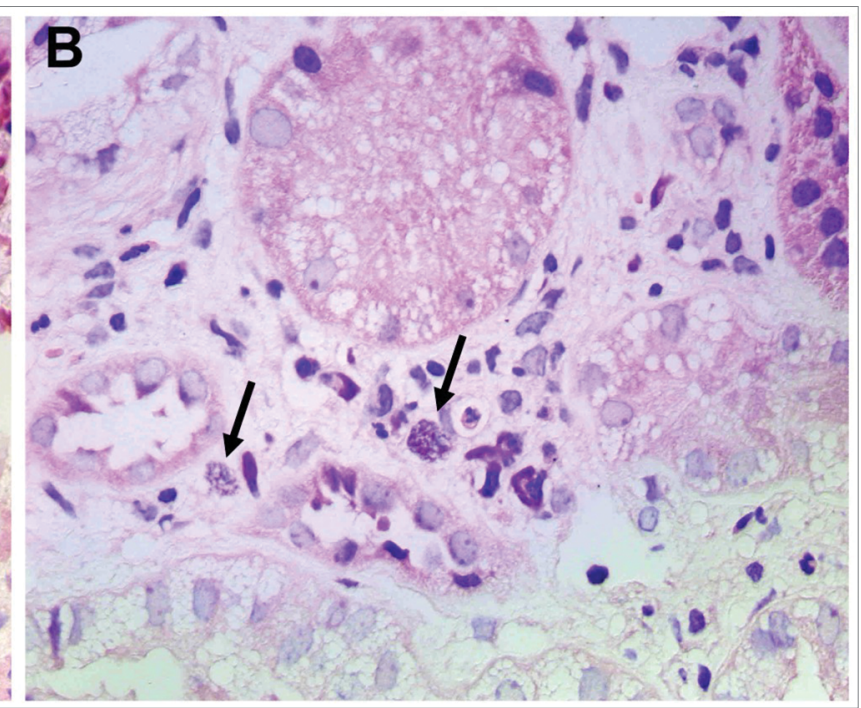

a region characterized by intense racial mixing, with many significant differences compared with European studies such as one looking into children and adolescents with LN in Italy, in which all included individuals were Caucasians. ${ }^{21}$

In terms of class of disease, our findings showed good agreement with other studies performed with pediatric patients, in which the proportions of subjects with class I LN ranged from $0-0.7 \%$; the proportions of individuals with class II LN ranged from $0-19.3 \%$; the proportions of individuals with class III LN ranged from 17-30.2\%; the proportions of individuals with class IV LN ranged from $46.7-70 \%$; the proportions of individuals with isolated class V LN ranged from $10-13.3 \%$; the proportions of individuals with mixed class V LN ranged from $0-18.6 \% .^{16,17,21,22}$ In our study, $70 \%$ of the biopsies were consistent with proliferative LN (classes III or IV), as similarly reported in a study carried out in Asia, in which the proportion was $77 \% .{ }^{20}$ Universally regarded as the 
most frequent form of disease, class IV LN was the most prevalent type of disease in our study. ${ }^{23}$

The mean $\mathrm{AI}$ was $10.58 \pm 4.49$, and the mean $\mathrm{CI}$ was $3.26 \pm 2.17$. The mean values found for $\mathrm{AI}$ and CI in our study were similar to the values published in an Egyptian study, in which the mean AI was 10.12 and the mean CI 2.06. ${ }^{24}$ Latin American studies including adult patients reported a mean AI of $6.7 \pm 4.6$ and a mean CI of $2.0 \pm 2.7 .^{25}$ These discrepancies may stem from the differences in age of the included patients, since pediatric LN tends to be more aggressive than the disease in adults, ${ }^{26}$ as reflected in the higher chronicity and activity indices.

Creatinine levels were significantly higher in patients with class IV LN than in individuals with isolated or mixed class V LN. A similar study also described higher serum creatinine levels in patients with class IV LN. ${ }^{27}$ Higher serum creatinine levels in proliferative disease may be explained by the pathophysiology of the condition, since subendothelial immune complexes form in class III and IV LN and cause vascular obstruction by endothelial cell edema, leading to decreases in the glomerular filtration rate calculated as a function of serum creatinine. ${ }^{28}$

A significant positive correlation was observed between mast cell counts in the tubulointerstitial compartment and the activity and chronicity indices. The ROC curve also indicated that the presence of mast cells was a sensitive and specific factor to differentiate patients with an $\mathrm{AI}>12$ from individuals with an $\mathrm{AI}$ $\leq 12$, a finding suggestive of significant tissue injury and correlated with better chances of responding well to treatment. A similar study also found a correlation between mast cell counts and the two indices. ${ }^{27}$ The correlation found between mast cell counts and the activity index is warranted, since leukocyte infiltration, along with interstitial inflammation, are relevant elements in the activity index. Immune system cell infiltration is the key to the pathogenesis of SLE and include $\mathrm{B}$ and $\mathrm{T}$ cells, macrophages, dendritic cells, and mast cells. ${ }^{29}$ Activated mast cells can synthesize prostaglandin and leukotriene, which promote the release of cytokines such as tumor necrosis factor alpha, a potent inducer of other inflammatory cytokines, including IL-2 and IL-6. Mast cells, along with their mediators, interact with interstitial infiltration cells, thus contributing to local inflammation. ${ }^{30} \mathrm{~A}$ recent study also described an important correlation between mast cell counts in the kidneys and CD4, CD8, and CD68 inflammatory cell counts in interstitial infiltrate. ${ }^{31}$ Mast cell chymases and metaloproteinases can convert angiotensin I into angiotensin II, which has been associated with tubulointerstitial inflammation and increased expression of cytokines and growth factors. ${ }^{32,33}$

The correlation found between mast cell counts in the renal interstitium and the chronicity index is warranted, since interstitial fibrosis is an important element in the chronicity index. As mentioned above, activated mast cells can produce numerous mediators including renin, chymase, tryptase, metaloproteinases (MMP), and transforming growth factor beta (TGF-Beta). ${ }^{34}$ Renin is a substrate for the production of ATII; chymases and MMP-9 can convert ATI into ATII. The local increase in ATII levels promotes fibroblast activation, vasoconstriction, and increased expression of TGF-Beta in the renal interstitium. These events culminate with collagen synthesis and fibrosis. ${ }^{32}$

A significant positive correlation was observed between mast cell counts in the tubulointerstitial compartment and blood urea nitrogen levels, a finding also described in another study looking into primary kidney disease and diabetic nephropathy. ${ }^{35}$ An experimental study described greater mast cell counts in the kidneys of rats with nephropathy induced by a hyperlipid diet, and higher blood urea nitrogen levels compared with controls. ${ }^{36}$ These findings suggest the existence of a close relationship between mast cells in the renal interstitium and blood urea nitrogen.

A trend toward a negative correlation was also seen between mast cell counts in the tubulointerstitial compartment and serum albumin. This finding is apparently unheard of in the literature. We were unable to find other studies in which the same finding has been described for pediatric patients with LN. Differently from our study, the authors of a Chinese study found a positive correlation between mast cell counts in the renal interstitium and serum albumin in adults with anti-glomerular basement membrane glomerulonephritis. ${ }^{31}$ A study enrolling patients with diabetic nephropathy found that serum albumin levels were lower in patients with advanced disease, while mast cell counts in the renal interstitium increased with disease progression. ${ }^{34}$ These disagreements probably stem from the different pathophysiological mechanisms in effect in the studied conditions and reflect the need 
for additional studies to clarify the involvement of mast cells in renal disease.

After dividing the patients into groups based on presence of absence of nephrotic syndrome, we observed that the patients with nephrotic syndrome had higher mast cell counts in the tubulointerstitial compartment. Pediatric nephrotic syndrome is characterized by the presence of proteinuria, hypoalbuminemia, edema, and hyperlipidemia caused by increased permeability of the glomerular filtration barrier. ${ }^{37}$ Since proteinuria is a key sign of nephrotic syndrome, our findings are in agreement with other studies in which a significant positive correlation was observed between mast cell counts and proteinuria in adults with diabetic nephropathy ${ }^{34}$ or LN. ${ }^{27}$ Mast cells contain chymase and metaloproteinases in their cytoplasmic granules, which play a role in the conversion of ATI into ATII. ${ }^{32}$ Local increases in ATII levels cause increased urine protein levels. ${ }^{27}$ In addition, the association between proteinuria and tubulointerstitial mast cells may warrant the changes in the renal parenchyma subsequent to the onset of proteinuria. Proteinuria is an important risk factor for the development of tubulointerstitial damage, since it promotes the expression of inflammatory and profibrotic mediators that contribute to the influx of mononuclear cells, including mast cells. ${ }^{38}$

\section{Conclusion}

Mast cells are involved in acute and chronic disease. The correlation between mast cells and activity and chronicity indices indicate that they have the sensitivity and specificity required to identifying individuals with higher activity indices. Inflammatory cell infiltration and morphological differences between cell types in the inflammatory infiltrate are relevant factors in the assessment of the AI. Mast cells may be an additional tool for renal pathologists to better understand the pathophysiology of lupus nephritis.

\section{Acknowledgements}

The authors would like to thank the Federal University of Triângulo Mineiro and the staff with the Renal Pathology Laboratory at UFTM, namely Alberto José de Borba; Edson Aparecido dos Santos; Liliane Silvano Araújo; Lívia Alves Martins; and Vandair Gonçalves Pereira. This study was funded by the National Council for Scientific and Technological Development (CNPq), the Coordination for the
Improvement of Higher Education Personnel (CAPES), the Research Support Foundation of the State of Minas Gerais (FAPEMIG), and the Education and Research Foundation of Uberaba (FUNEPU).

\section{AUtHOR CONTRIBUTIONS}

Laura Penna Rocha: started and coordinated the original study; interpreted results; and wrote the manuscript.

Stéfany Silva Santos and Carolina Marques Ramos: collected data; performed morphometric analysis; and wrote the manuscript.

Maria Luiza Gonçalves dos Reis Monteiro and Juliana Reis Machado: performed statistical analysis; contributed with the interpretation of study results.

Marlene Antônia dos Reis: performed diagnostic examinations in all cases; and contributed with the interpretation of study results.

Rosana Rosa Miranda Corrêa: contributed with the interpretation of study results; and wrote the manuscript.

\section{Conflict of InTEREST}

The authors had no conflict of interest to declare.

\section{References}

1. Weening JJ, D'Agati VD, Schwartz MM, Seshan SV, Alpers CE, Appel GB, et al. The classification of glomerulonephritis in systemic lupus erythematosus revisited. J Am Soc Nephrol 2004;15:241-50.

2. Hiraki LT, Benseler SM, Tyrrell PN, Hebert D, Harvey E, Silverman ED. Clinical and laboratory characteristics and longterm outcome of pediatric systemic lupus erythematosus: a longitudinal study. J Pediatr 2008;152:550-6.

3. Ehara T, Shigematsu H. Mast cells in the kidney. Nephrology (Carlton) 2003;8:130-8.

4. Hiromura K, Kurosawa M, Yano S, Naruse T. Tubulointerstitial mast cell infiltration in glomerulonephritis. Am J Kidney Dis 1998;32:593-9.

5. Roberts ISD, Brenchley PE. Mast cells: the forgotten cells of renal fibrosis. J Clin Pathol 2000;53:858-62.

6. Holdsworth SR, Summers SA. Role of mast cells in progressive renal diseases. J Am Soc Nephrol 2008;19:2254-61.

7. Tomito Y. Predictors of prognosis in IgA nephropathy. Kaohsiung J Med Sci 2012;28:517-20.

8. Bradding P, Pejler G. The controversial role of mast cells in fibrosis. Immunol Rev 2018;282:198-231.

9. Wallace D, Hahn B, eds. Dubois' Lupus Erythematosus and Related Syndromes. 8th ed. Philadelphia: Elsevier/Saunders; 2013.

10. Morel-Maroger L, Méry J, Droz D, Godin M, Veroust P, Kourilsky $\mathrm{O}$, et al. The course of lupus nephritis: contribution of serial renal biopsies. Adv Nephrol Necker Hosp 1976;76:79-118.

11. Austin HA 3rd, Muenz LR, Joyce KM, Antonovych TA, Kullick ME, Klippel JH, et al. Prognostic factors in lupus nephritis: contribution of renal histologic data. Am J Med 1983;75:38291. 
12. Hill GS, Delahousse M, Nochy D, Tomkiewicz E, Rémy P, Mignon F, et al. A new morphologic index for the evaluation of renal biopsies in lupus nephritis. Kidney Int 2000;58:1160-73.

13. Ribatti D. The Staining of Mast Cells: A Historical Overview. Int Arch Allergy Immunol 2018;176:55-60.

14. Ribeiro AS, Pimentel LD, Ferro AB, Araújo C. Azul de toluidina, giemsa e violeta de cresil na evidenciação e mastócitos. Rev Téc Anat Patol 2014;18:5-10.

15. Singh S, Abujam B, Gupta A, Suri D, Rawat, A, Saikia B, et al. Childhood lupus nephritis in a developing country-24 years' single-center experience from North India. Lupus 2015;24:6417.

16. Srivastava P, Abujam B, Misra R, Lawrence A, Agarwal V, Aggarwal A. Outcome of lupus nephritis in childhood onset SLE in North and Central India: single-centre experience over 25 years. Lupus 2016;25:547-57.

17. Taheri S, Beiraghdar F. Lupus nephritis in Iranian children: a review of 60 patients. Ren Fail 2011;33:499-505.

18. Batinić $\mathrm{D}$, Milošević $\mathrm{D}$, Čorić $\mathrm{M}$, Topalović-Grković $\mathrm{M}$, Jelušić $\mathrm{M}$, Turudić D. Lupus nephritis in Croatian children: clinicopathologic findings and outcome. Lupus 2015;24:307-14.

19. das Chagas Medeiros MM, Bezerra MC, Braga FN, da Justa Feijão MR, Gois AC, Rebouças VC, et al. Clinical and immunological aspects and outcome of a Brazilian cohort of 414 patients with systemic lupus erythematosus (SLE): comparison between childhood-onset, adult-onset, and late-onset SLE. Lupus 2016;25:355-63.

20. Sato VA, Marques ID, Goldenstein PT, Carmo LP, Jorge LB, Titan SM, et al. Lupus nephritis is more severe in children and adolescents than in older adults. Lupus 2012;21:978-83.

21. Ruggiero B, Vivarelli M, Gianviti A, Benetti E, Peruzzi L, Barbano G, et al. Lupus nephritis in children and adolescents: results of the Italian Collaborative Study. Nephrol Dial Transplant 2013;28:1487-96.

22. Jebali H, Hajji M, Rais L, Hamida FB, Beji S, Zouaghi MK. Clinicopathological findings and outcome of lupus nephritis in Tunisian children: a review of 43 patients. Pan Afr Med J 2017;27:153.

23. Wu JY, Yeh KW, Huang JL. Early predictors of outcomes in pediatric lupus nephritis: focus on proliferative lesions. Semin Arthritis Rheum 2014;43:513-20.

24. Elmougy A, Sarham A, Hammad A, El-Refaey A, Zedan M, Eid $\mathrm{R}$, et al. Lupus nephritis in Egyptian children: a 16-year experience. J Nephrol 2015;28:557-62.

25. Pinto Peñaranda LF, Castro Mercado IL, Duque Caballero V, Márquez Hernández JD, Velásquez Franco CJ. Predictive risk factors for failure to induction therapy of lupus nephritis in a cohort of Colombian patients. Reumatol Clin 2014;10:147-51.

26. Groot N, de Graeff N, Marks SD, Brogan P, Avcin T, BaderMeunier B, et al. European evidence-based recommendations for the diagnosis and treatment of childhood-onset lupus nephritis: the SHARE initiative. Ann Rheum Dis 2017;76:196573.

27. Kaczmarczyk K, Kosalka J, Soja J, Kuzniewki M, Musial J, Okon K. Renal interstitial mast cell counts differ across classes of proliferative lupus nephritis. Folia Histochem Cytobiol 2014;52:218-24.

28. Liu Y, Anders HJ. Lupus nephritis: from pathogenesis to targets for biologic treatment. Nephron Clin Pract 2014;128:22431.

29. Kaczmarczyk K, Musiał J, Soja J, Kuźniewski M, GalaBłądzińska A, Białas $\mathrm{M}$, et al. Renal interstitial mast cell count is significantly higher in membranoproliferative glomerulonephritis than in class IV lupus nephritis. Pol J Pathol 2015;66:149-53

30. Sashidhara KV, Rosaiah JN, Tyagi E, Shukla R, Raghubir R, Rajendran SM. Rare dipeptide and urea derivatives from roots of Moringa oleifera as potential anti-inflammatory and antinociceptive agents. Eur J Med Chem 2009;44:432-6.

31. Wu XM, Zhang YY, Zhang MC, Zhang LH, Zeng CH, Liu $\mathrm{ZH}$, et al. Significance of mast cell renal infiltration in patients with anti-GBM nephritis. Renal Fail 2016;38:906-13.

32. Veerappan A, Reid AC, O'Connor N, Mora R, Brazin JA, Estephan $\mathrm{R}$, et al. Mast cells are required for the development of renal fibrosis in the rodent unilateral ureteral obstruction model. Am J Physiol Renal Physiol 2012;302:192-204.

33. Durán-Barragán S, McGwin G Jr, Vilá LM, Reveille JD, Alarcón GS; LUMINA (LIX): a multiethnic US cohort. Angiotensin-converting enzyme inhibitors delay the occurrence of renal involvement and are associated with a decreased risk of disease activity in patients with systemic lupus erythematosus--results from LUMINA (LIX): a multiethnic US cohort. Rheumatology (Oxford) 2008;47:1093-6.

34. Zheng ZH, Zhang LJ, Liu WX, Lei YS, Xing GL, Zhang JJ, et al. Predictors of survival in Chinese patients with lupus nephritis. Lupus 2012;21:1049-56.

35. Okón K, Stachura J. Increased mast cell density in renal interstitium is correlated with relative interstitial volume, serum creatinine and urea especially in diabetic nephropathy but also in primary glomerulonephritis. Pol J Pathol 2007;58:193-7.

36. Reena TK, Kaur A, Singh M, Buttar HS, Pathak D, Singh AP. Mast cell stabilizers obviate high fat diet-induced renal dysfunction in rats. Eur J Pharmacol 2016;777:96-103.

37. Andolino TP, Reid-Adam J. Nephrotic Syndrome. Pediatr Rev 2015;36:117-25.

38. Li Y, Zhou L, Liu F, Peng Y, Li J, Sun L, et al. Mast cell infiltration is involved in renal interstitial fibrosis in a rat model of protein-overload nephropathy. Kidney Blood Press Res 2010;33:240-8. 